\title{
Prophetic Conflict in Jeremiah 27-28 and the Question of True and False Prophecy
}

\author{
Ikenna L. Umeanolue \\ http://dx.doi./org/10.4314/ujah.v21i2.5
}

\begin{abstract}
The Old Testament text of Jeremiah 27-28 presents prophetic conflict between Jeremiah and Hananiah. Jeremiah proclaimed a message of God's judgment against the rulers and the people of Judah because of their violation of the religious and the legal traditions of the nation but Hananiah opposed him preaching a message of peace and salvation and predicted the deliverance of Israelite nation from the hands of their enemies. Both claimed to have God's authority. Jeremiah 27-28 provides a window into the problem of discerning a true prophet from a false one. Contemporary Nigerian Christians are also being challenged with such opposing prophecies by prophets who claim that their prophecies come from God. This study adopts exegetical method of interpretation and application of the message of Jeremiah 27-28 to the fact of truity and falsity in prophecy in contemporary Christianity. This study discovered that true prophetic office is a call, and not all comers' affair. Prophecy lacks empirical proof and is sometimes manipulative and susceptible to barratry. The study further discovered that true prophets prophesy by the spirit of God while false Prophets prophesy from their own mind but also claim to do so by the spirit of God. Just like Prophet Hananiah, there are prophets who could be genuinely called but have refused to stay within their call because of loss of focus and desire for material gains. Thus the prevalent worldview of contemporary Nigerians concerning easy solution to life's problems that leads to abuse of prophetic consultations needs to be changed.
\end{abstract}


Keywords: Jeremiah 27-28, prophecy, prophet, prophetic conflict, true, false, Nigerian Christians

\section{Introduction}

Within the development of the prophetic movement in Israel during the period of the monarchy, there arose two types of prophets. The first type was a group of independent prophets who claimed to speak on behalf of Yahweh and whose primary function was to challenge the awful policies of the king. These prophets also warned the people to return to the old traditions of the covenant. The second type was a group of prophets who were paid by the temple or the court and who proclaimed the kind of message their patrons desired to hear. This group of prophets came to be known as false prophets, not because of their desire to mislead the people, but rather, because they misinterpreted Yahweh's intentions at times when the nation was facing great dangers. According to Vangemeren (1990), in times of moral darkness the false prophets, predicting smooth things for the nation, independent of repentance, consecration and the pursuit of spiritual ideas, were honoured above the true prophets who emphasized the moral greatness of Yahweh and the necessity of righteousness for the nation. Two prophets who represent these styles of prophetic ministries are Jeremiah and Hananiah (Jeremiah 27-28) who are the chief actors in the chosen passage of study. Jeremiah spoke truly in the name of Yahweh, Hananiah spoke falsely in the name of Yahweh, and the central question is how to understand and distinguish true and false prophecy.

The encounter between Jeremiah and Hananiah took place in the temple (Jer. 28:1). The temple signifies God's presence among his people. As preachers of the divine mind, the prophets should always deliver the true message of God. Contrarily, two 
conflicting messages are presented in Jeremiah $27-28$ by the prophets Jeremiah and Hananiah. Faced with two contradictory views of God's work, which one should the people accept as the legitimate interpretation of God's will? Which prophet was applying prophetic tradition properly to determine what God was doing in the current situation? The contemporary Judeo-Christians are also being confronted with such opposing prophecies by Christian prophets and ministers who claim that their prophecies came from God.

This paper, therefore, examines the question of truism and falsity in prophecy with particular reference to the prophecies of Jeremiah and Hananiah in Jeremiah chapters 27-28 and its implications for contemporary Nigerian Christians. The study adopts exegetico- hermeneutical method of biblical interpretation which facilitates the application of the narrative message of Jeremiah 27-28 to the contemporary Christians.

Etymologically, the English word prophecy comes from the Greek verb prophemi which means 'to speak for'. Thus prophecy is God's message delivered by the prophet who speaks on behalf of God. According to Price (1984), "Prophecy is an inspired communication from God" (p. 396). Literally, prophecy means speaking for, or on behalf of God (Matthews, 1918; Mowvley, 1979; Obielosi, 2012). For Ugwueye (2002), prophecy is not specifically or even principally the forecasting of the future but rather the mediation and interpretation of the divine mind and will (p. 3). Operationally, the term prophecy is defined as the word of God proclaimed by a prophet commissioned by God to speak for him publicly to the people. The Hebrew word ${ }^{\prime}$. Idenotes one who communicates divine revelation. The Hebrew Bible applies this word both to the so-called false prophets of Israel or even to the 
prophets of other religions like Baalism as well as for the genuine prophets of Yahweh.

From the beginning, Old Testament prophets grew into quite distinctive persons. Several examples of this kind of religious persons have been collected together by Lindblom (1973). He enumerates a number of characteristics which enable one to describe a person as prophetic and then uses this as a kind of check-list against which certain individuals and groups of people may be examined: They must be wholly devoted to the god whom they worship; they are inspired and under divine constraints showing signs of ecstasy and abnormal behaviour; they receive revelations from their god and announce them publicly; they have a special call from the deity to fulfill his purpose unconditionally. This would be a fair description of Israelite prophets.

The Old Testament shows how false prophets told kings exactly what they wanted to hear, to garner favour for their own personal gain. There is no hint of their complete disappearance until the end of the fourth century (Zech. 13:2). Under Ahab, they declared to the king that he should make war on Ramoth-Gilead, with the certainty of capturing the town; in fact he was defeated and killed (3 Kings 22). In the time of Jeremiah, Hananiah addressed the people and priests in Jerusalem and foretold the overthrow of Nebuchadnezzar, because that was what everyone was hoping to hear (Jer. 28)

\section{Prophetic Conflict in Jeremiah 27-28: An Exegetical Analysis} Jeremiah 27 and 28 record the conflict Jeremiah had with false prophets in Jerusalem before the Babylonian captivity. The events depicted in these chapters took place in the period between the first and second deportations of Judeans to Babylon. According to Dyer and Merrill (2001), the events recorded may have happened 
sometime after a failed coup attempt against Nebuchadnezzar in Babylon in December of 595 and January of 594 B.C. Overholt (1967) is of the view that the dominant theme of these chapters find expression in the following structure: general message to those who remain in Jerusalem concerning service to Nebuchadnezzar and the length of the exile (Jer. 27) and a specific example of prophetic opposition to this message at home (Jer. 28).

Jeremiah 27 has to do with Jeremiah's warning against making a coalition to resist king Nebuchadnezzar of Babylon. This chapter of Jeremiah contains three sections: Jeremiah's prophecies to the foreign messengers (vv. 1-11), his appeal to King Zedekiah (vv. 12-15), and his appeal to the priests and people of Jerusalem (vv. 16-22), that God has laid on them the yoke of the king of Babylon, and that they ought to humble themselves under his almighty hand (Mandel, 2006; Keil and Delitzsch, 2006). Each of the sections contains, principally, a two-part exhortation: Do not believe the prophetic lie ( $า .7$ but do serve the king of Babylon. According to Vine (1996), the word 7.8 שoccurs 113 times in the Old Testament. The first occurrence is in Exodus 5:9. In about thirty-five passages, רש describes the nature of "deceptive speech": to speak (Is. 59:3), to teach (Is. 9:15), to prophesy (Jer. 14: 14), to lie (Mc 2:11). It may also indicate a "deceptive character" as expressed in one's acts: to deal treacherously (2 Sam. 18:13) and to deal falsely (Hos. 7:1). In Jeremiah 27 and 28, ר. used as a prophetic lie.

In Jeremiah 27:1-11, the yoke Jeremiah is to make and lay on his neck is a plain emblem of the Babylonian yoke the nations

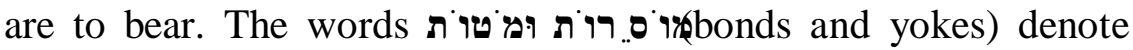
together one yoke. טו

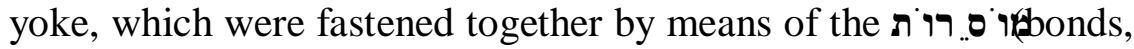
ropes) so that the yoke might be laid on the beast's neck (cf. Lev. 
26:13). That Jeremiah really put such a yoke on his neck and wore it is seen from 28:10, 12, where a false prophet breaks it for him. $\mathrm{He}$ is to send the yoke to the kings of Edom, Moab, etc., by means of envoys of those kings, who have come to Jerusalem to Zedekiah. Though this might have sufficed to accomplish the aim of the prophecy, it is difficult to reconcile it with the wording of the text; hence "bonds and yokes" may indeed mean a single yoke, but it may also

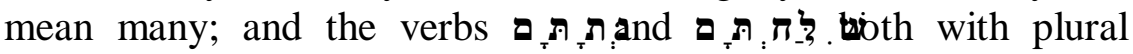
suffixes, indicate clearly that he was to make not merely one yoke for himself, but yokes for himself and the kings. In Jeremiah 28:10

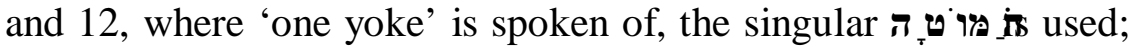
while "yokes of wood has thou broken" in v. 13 does not prove that this plural has the same force as the singular.

Jeremiah charged the people not to hearken to the prophets, soothsayers, and sorcerers that deliver false prophecies. The enumeration of the multifarious means and methods for forecasting the future is designed to show the multitude of delusive schemes for supplying the lack of true and real divine inspiration.

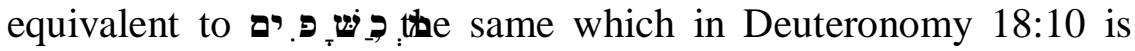
used along with is disputed. Some take it from meaning cloud - cloud-maker or storm-maker; others from i. meaning eye - fascinator, the idea being that of bewitching with the evil eye (cf. Lev. 19:26). The use

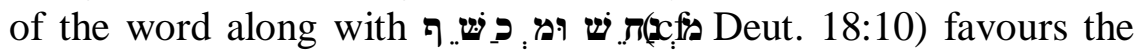
latter rendering, whereas no passage in which the word is used in the Old Testament supports the idea of it meaning storm-raiser. The false prophets delude the people, inciting them to rise in rebellion against Nebuchadnezzar, contrary to God's will, and thus simply bringing about their expulsion from their land, i.e., removal

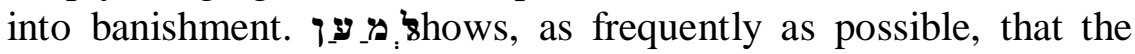


inevitable consequence of these false prophets' proceedings is designed by them. Zedekiah and the ambassadors that had come to him might have learnt from Nebechadnezzar's course of action after the capture of Jerusalem under Jehoiachin, as compared with that in Jehoiakim's time, had they not been utterly infatuated by the lying spirit of the false prophets, whose prophecies accommodated themselves to the wishes of the natural heart.

The imperative $ו \pi$.intimates the consequence of the preceding command. Verse 13 gives the application of the threat in v. 8 to King Zedekiah and his people; and v. 14ff gives the warning corresponding to vv. 9 and 10 against the sayings of the false prophets (cf. Jer. 14:14; 23:16, 21). In chapter 27:14-15 Jeremiah told Zedekiah not to listen to the false prophets who were advocating resistance because Yahweh had not sent them. Listening to their advice would result in exile and death for the king and the false prophets. For Feinberg (1986), "To underestimate the power of a lie in times of national distress is sheer folly" (p. 545).

Jeremiah 27:17 advises the priests and people not to listen to these false prophets. They should submit to Nebuchadnezzar and live rather than resisting and see Jerusalem destroyed. According to Jeremiah 27:18, if the false prophets were true, they should ask Yahweh to keep the remaining furnishings and accessories still in Jerusalem from being taken captive to Babylon (cf. 2 Kings 25:1317; Dan. 1:1-2). The granting of their petition would validate them as authentic prophets. Jeremiah 27 concludes with verse 19-22. Here, the Lord's word concerning these treasures of the temple, palace, and city was that Nebuchadnezzar would take them to Babylon where they would remain until the Lord restored His people to their land (cf. Ezra 1:7-11). 
Jeremiah 28 has to do with Jeremiah's conflict with the false prophet, Hananiah. Keil and Delitzsch (2006) divide Jeremiah 28 into three sections: Jeremiah's conflict with the false Prophet Hananiah (vv. 1-4), Jeremiah's reply to Prophet Hananiah (vv. 511), and Yahweh's testimony against Hananiah (vv. 12-17). In the first section, the false prophet Hananiah endeavours to stamp on his prediction the impress of a true, God-inspired prophecy, by copying the title of God, so often used by Jeremiah, "Yahweh of hosts, the God of Israel", and by giving the utmost definiteness to his promise: "within two years" (in contrast to Jeremiah's seventy years). "Two years" are made as definite as possible by the addition of ?ז. two years in days, i.e., in two full years (cf. Gen. 41:1; II Sam. 13:23).

In Jeremiah 28:2-3, Hananiah prophesied that Yahweh had broken Babylon's authority over Judah. Within two years the Lord would return to the temple the vessels that Nebuchadnezzar had already taken to Babylon. חִיח (Hananiah), whose name means "Yahweh has been gracious", announced a message that Yahweh would be gracious. Jeremiah predicted that the captivity would last 70 years (Jer. 25:11-12; 29:10), but Hananiah predicted it would last only two years. The Lord would also return Jeconiah (Jehoiachin) and the people who went with him to Babylon as captives, Hananiah predicted, because Yahweh would break Babylon's yoke (Jer. 28:4). This flatly contradicted Jeremiah's prophecy that Jeconiah would die in Babylon (Jer. 22:24-27; cf. 52:31-34).

It cannot be charged, for example, that the prophet Hananiah speaks without obvious authority, for he comes forward in the name of Yahweh (Jer. 28:2, 11). Hananiah is no mere impostor, and it is clear that his "falsity" is not immediately obvious to Jeremiah. In Jeremiah 28:8 Jeremiah presents a 
characterization of the prophetic vocation as his justification in the conflict with Hananiah: "The prophets who preceded you and me from ancient times prophesied war, famine, and pestilence against many countries and great kingdoms'. Here, there is neither a series of prophets nor a prophetic office, but simply the mention of the prophecies of the prophets who have preceded Jeremiah and Hananiah from ancient times. Especially noteworthy is the

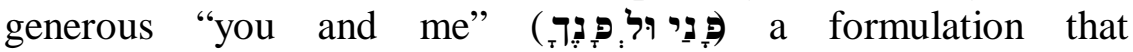
unquestionably includes Hananiah in the group of prophets Hananiah is not a false prophet in the ontological sense, but merely a prophet who in this particular case has delivered himself of words not of the Lord and thus has spoken falsely (Gallagher, 2014).

In Jeremiah 28:5-9, Jeremiah first admits that the fulfillment of this prediction would be desirable (v. 6), but then reminds his opponent that all the prophets of the Lord up till this time have prophesied of war and calamity (vv. 7 and 8). So that if a prophet, in opposition to these witnesses of God, predicts nothing but peace and safety, then nothing short of the fulfillment of his prediction can make good his claim to be a true prophet (v. 9). Jeremiah started answering with the word Amen). The scope

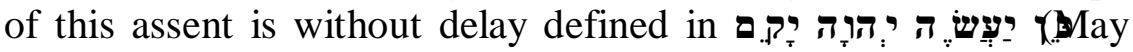
Yahweh so do). But in order that the hearers may understand his assent, Jeremiah proceeds to show that hitherto only threatening predictions have carried with them the presumption of their being true prophecies, inasmuch as it is these alone that have been in harmony with the predictions of all previous prophets. אוֹ 8 is explained by the fact that "the prophets" with the accompanying relative clause is made to precede absolute-wise. In the same absolute manner the clause "the prophet... peace" is disposed so that after the verb $y$. 
expressed in v. 9 is based on the Mosaic Law concerning prophecy (Deut. 18:21f.), where the fulfillment of the prophecy is given as the test of true, God-inspired prophecy.

Hananiah is not attacked because of the form in which he received his revelation, and no mention is made of any personal immorality. Even though Jeremiah himself mentions the fulfillment of prophecy as a check on the validity of Hananiah's message (Jer. 28:9), it is evident that the contest is not resolved in that way. Jeremiah apparently did not wait for two years to elapse before returning to confront his opponent, nor does he even mention the matter of non-fulfillment (cf. Jer. 28:12-16). To all outward appearances, Hananiah was also a true prophet of Yahweh. If he is to be identified as a "false" prophet, this must be done from the point of view of the message he brought to the people. Hananiah asserts that the fortunes of the city are about to be restored (Jer. 28:2-4, 10ff.). In doing so he stood firmly within the tradition of the prophet Isaiah, who was convinced that Zion would never fall.

Had Hananiah been sent by the Lord, he might have been satisfied with Jeremiah's opinion, and might have contently awaited the issue. But instead of this, he seeks by means of violence to secure credence for his prophecies (Jer. 28:10f.). He takes the yoke from off the neck of the prophet, and breaks it in pieces, as he repeats before the people his former prediction: "Thus says Yahweh: Even so will I break the yoke of Nebuchadnezzar king of Babylon from the neck of all nations within two years". Thereupon Jeremiah went his way without answering a word, calmly entrusting to the Lord the vindication of the truth of His own word. Apparently not long after Jeremiah had departed, he received from the Lord the commission to go to Hananiah and talk

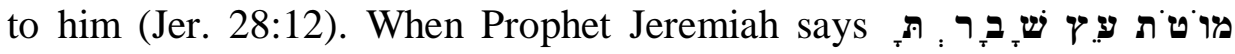


(You have broken wooden yokes), one is not to understand him as speaking of the breaking of the wooden yoke Jeremiah had been wearing; he gives the deeper meaning of that occurrence. By breaking Jeremiah's wooden Yoke, Hananiah has only signified that the yoke of Nebuchadnezzar lays on the nations will not be so easily broken as a wooden one, but is of iron, i.e., not to be broken. The plural a inokes) is to be explained by the emblematical import of the words, and is not here to be identified, as it sometimes may be, with the singular (vv. 10 and 14) which shows in what sense Hananiah put an iron yoke in the place of the wooden one.

Jeremiah responded to Hananiah sincerely but ironically. So be it, he said. Jeremiah wished that Hananiah's prophecy would come true because he loved his people and his land and did not want them to experience the horrors of invasion and a long exile. Yet Jeremiah urged the people to listen to what he was about to say to them (Jer. 28:7). Time would tell, he said, whether Hananiah's prophecies of peace or Jeremiah's prophecies of war were truly from Yahweh (Jer. 28:8-9). One of the tests (not in all cases) of a true prophet in Israel was the fulfillment of his predictions (cf. 23:16-40; Deut. 18:21-22). Jeremiah's meaning was that the usual message of the earlier prophets was one of doom, and that when he spoke of judgment he was more in the line of the predecessors than Hananiah, who spoke only of peace and prosperity.

In Jeremiah 28:10-11, Hananiah proceeded to deliver a symbolic act of his own by vandalizing Jeremiah's sign. He dramatically smashed the yoke that Jeremiah had been wearing on his neck (cf. Jer. 27:2). He claimed that similarly within two years Yahweh would break the yoke of Nebuchadnezzar off the neck of all the nations that he was oppressing. In Jeremiah 28:12-13, shortly after these events, the Lord told Jeremiah to return to 
Hananiah with a message. He told Hananiah that by breaking the wooden yoke off Jeremiah's neck he had only made Nebuchadnezzar's oppression more certain. Failure to repent had resulted in more certain judgment. Jeremiah told Hananiah that Yahweh of Hosts, Israel's God, said that all the nations would serve Nebuchadnezzar (Jer. 28:14). The Babylonian king would even control the beasts; his supremacy would be total. Nothing the people could do would divert this judgment (cf. Acts 20:26-27). His yoke over them was as unbreakable as iron (cf. Jer. 15:12).

In Jeremiah 28:15-16, Hananiah is said by Jeremiah not to be 'sent' (ל ל by Yahweh, and to be making the people trust in a 'lie' (ר. "Yahweh did not send you, and you are causing this people to trust in a lie" (Jer. 28:15). The first element of this charge might be paraphrased, "Yahweh did not send you in this situation with this particular message". Because of this fact the breaking of the yoke bars was pointless. Furthermore, the Lord had revealed that He would take Hananiah's life within a year because he had encouraged the people to rebel against the Lord's word.

The penalty that false prophets were to suffer under the Mosaic Covenant was death (Deut. 18:20). The words (for you have spoken rebellion against Yahweh) recall Deuteronomy 13:6. They involve an application to Hananiah's case of the command there given to put such a prophet to death, and show how it can with justice be said that the Lord will cast him from off the face of the earth. The verb sake of the play on people, but will send him away from off the earth, i.e., cause him to die. In v. 17 it is recorded that this saying was soon fulfilled. Hananiah died in the seventh month of that year, i.e., two months after his controversy with Jeremiah (cf. v. 1). 
Sure enough, as stated in Jeremiah 28:17, about two months later Hananiah died. The prophet who predicted deliverance in two years died in two months. God graciously gave him two months to repent before He put him to death. His death was another object lesson to the people on the importance of obeying God's word. Jeremiah survives to see the fulfillment of the prophecies given to him by the Lord.

\section{Criteria for Distinguishing True and False Prophecy}

When Jeremiah returns with a new word of God, he objects to Hananiah's announcement of salvation on two grounds. First, he appeals to the precedent of prophets who prophesied God's judgement on the nation (28:8); secondly, he says that a prophecy of salvation only demonstrates its authority when it is fulfilled (28:9; cf. Deut. 18:22). These two criteria do not stand up as objective measures for determining true prophecy (Gallagher, 2014). The first criterion appeals selectively to historical precedent, as the prophets before Jeremiah were not fully and simply prophets of doom and judgement. There is a tradition of prophets proclaiming salvation just as there is one of the prophets preaching judgement. The second criterion also appears weak, Jeremiah is effectively saying that the prophet of judgement stands in a chain of tradition and hence requires no further legitimisation, while the prophet of salvation does not have that assurance and therefore he must prove himself through the fulfilment of his prophecies. Apart from the apparent double standard, this waitand-see criterion comes too late for the witnesses of this confrontation who need to decide and act now in the midst of the national crisis. There is no time to wait for the fulfilment of Hananiah's prophecy or, as it turned out, the hour of his death. 
One can hardly ultimately verify the claims of a prophet because the prophet purports to speak of God, a claim which is beyond the scrutiny of reason. Von Rad (1968) speaks of these two arguments against Hananiah as 'almost groping'. According to Carroll (1981), these are hardly criteria at all: "Writing from the context of the exile, the presenters of the Jeremiah tradition did not need to determine which prophets were true and which false; they already knew" (p. 187). To be sure, these criteria were written after the fact, and the motivation for recording them was to use them as a foil for treating future cases of prophecy. That the conflict between Jeremiah and Hananiah was used in this way should not lead us to follow Carroll in reducing its redaction to a simple vindication of Jeremiah or a reinforcement of deuteronomistic ideology. But Jeremiah's prophecy of a long exile does vindicate him; his moral character as well as his willingness to speak God's words of warning and judgement to the people even upon the penalty of death, further demonstrates that he is a true prophet. We shall gain a greater insight into what constitutes true prophecy in ancient Israel by taking these criteria at face value in order to see more clearly why Jeremiah (or at least his redactors), regards them as indispensable in the verification of prophecy.

Consider the judgement criterion first. A primary criticism of the false prophets is the reassuring nature of their message: they tell the people what they want to hear. As Jeremiah informs us in 5:12 and 23:17, they assure their audience that no evil will come upon the nation. This message that all is well stands in sharp contrast of Jeremiah's words of judgement. Such reassurances of the status quo do not lend themselves to the prophetic task of getting people to turn to God. According to Gallagher (2014), a prophecy of tribulation is one of the means by which to capture the attention of the people and to compel them to turn to God. This 
note of judgement and return to true worship of God is conspicuously absent in Hananiah's message at this critical hour in the nation's history.

As for the second criterion, why should a testimony of judgment be more plausible than one of salvation, only because the first is directed against the trend of the time? The point is not the voicing of prophetic judgements per se but their background, namely, the guilt of the nation. The heavy emphasis on prophetic judgement in 28:8 points to the theological situation of the exilic community in Jeremiah's time. At the time of Jeremiah, the judgement prophecies had largely proved themselves goodness among the present generations; there is scarcely an honest person to be found $(5: 1 ; 6: 13)$, even among one's own neighbours and kin (9:4-6). While Jeremiah may have been overstating his case for the wickedness of the current generation, his words against the nation and Zedekiah point to a significant decline in religious and civil life since the religious reforms of Josiah. Such a decline should give any prophet pause before declaring a deliverance from the nation's enemies.

Yet Jeremiah does not rebuke Hananiah; on the contrary, when his opponent breaks the yoke (28:11), he falls silent and retreats. Did Jeremiah falter, lose confidence in his own word of prophecy in that moment? Or perhaps Jeremiah recognises the possibility that the Lord may change his plan, that he may send a word to a prophet, Jeremiah would know that Hananiah was wrong. In light of the transgressions of the people and their lack of repentance, Jeremiah also knows that it is highly unlikely that God had a short exile in mind. Indeed, the word given to Jeremiah, in response to Zedekiah's request for guidance during the siege of Jerusalem, leaves no room for an early restoration of the kingdom (21:12-14). A more plausible interpretation of Jeremiah's silence 
can be found in the silence of Jesus before Herod (Luke 23:9), for what other reply than silence can there be to such blatant falsehood?

Jeremiah's silence reinforces his credentials as a true prophet. An immediate response from Jeremiah would place him in the company of the false prophets who only speak from out of their own minds $(23: 16,26)$, who prophesy without being sent (23:21, $32 ; 28: 15)$. The false prophets act on their own initiative. Jeremiah only speaks prophetically when a word of God has been put on his lips. In 42:7, Jeremiah waits ten days for an answer to a specific question. Hananiah comes across as one ready for a political debate on the question of a short or a long exile with all its attendant drama and quick retorts. Jeremiah, attending to God's word and not his own reasoning and powers of rhetoric, can only withdraw and wait upon God for a reply to his swift-speaking opponent.

\section{Implications of Jeremiah 27-28 for Contemporary Nigerian Christians}

Jeremiah 27-28 has implications for the contemporary Nigerian Christians. Many contemporary Christians have been deceived by false prophecies which they thought were genuine just like the Israelites of Jeremiah's time (Opeyemi, 2009). Jeremiah 27-28 alerts and educates us that there are false prophets both inside and outside every religious sanctuary.

Many people believe that a prophet is someone who predicts a specific event that comes to pass. Prediction is only an infinitesimal aspect of prophecy and even a false prophet's prediction may come to fulfillment as a test to God's faithful followers. In reality, a true prophet is someone who is calling people who have gone astray to return and enter into a right 
relationship with God (Ugwueye and Umeanolue, 2015. To properly listen to a true prophet of God is to respond to their message before it is too late to do anything about it. The prophecies of Jeremiah and Hananiah in Jeremiah 27-28 therefore imply that the role of a true prophet is to call God's backslidden people into a right spiritual relationship with him. The true working of a false prophet is to persuade God's backslidden people that there is no need to repent or reconcile with God. False prophets often confuse the issue by turning the true message of God around to mean its exact opposite just to please their hearers.

The passage strongly highlights the implication of 'prophetic lie' to God's work. The essence of telling a lie is basically to distort the truth. According to Ugwueye (2004) to use speech in a manner contrary to that for which it was not intended for is certainly intrinsically evil. A lie told in our ordinary life is usually capable of causing discomfort and catastrophe of different proportions. A lie told with the claim that God is the one speaking had in the past caused the death of many people, led communities and nations into war, made people to be fanatical and caused many to live in fools' paradise for years. As the passage under review pointed out a prophetic lie deceives and may not be immediately obvious to the listeners that have being told a lie.

When a lie is told, especially a prophetic one, the liars go to any length to defend and protect the lie in order to make it what it is not. Hananiah had to break the wooden yoke on Jeremiah's neck just to sustain the lie he had told. The essence of true prophecy is to call for repentance. False prophecy promotes and postpones the evil day. Problems are deepened by prophetic lies because they make people not to repent thereby making God's judgment more certain. 
Those who are behind prophetic lies are the false prophets. Any where they are in Christendom, they must be aware of the implication of what they are doing. The type of judgment that came upon the false prophets in Judah during the time of Jeremiah awaits them if they fail to repent (Jer. 13:13-15; 29:31-32). Failure to repent has in the past given rise to additional harsh verdict.

Calmness and absolute trust in God at all times as exhibited by Jeremiah throughout the encounter with Hananiah are of far reaching implication for true prophets and Christians in the contemporary society. A true prophet by virtue of the prophetic work can meet with opposition, hatred, insult, challenges and even violence; what is needed on their part is Jeremiah's consistent calmness and unwavering trust in the one and only author of genuine prophecy.

\section{Conclusion}

The prophetic conflict in Jeremiah 27-28 is complex and complicated for the people's understanding of the prophets. People are so inclined to prophecy that they visit prayer houses where they are given the message of what will happen in near future. But the growth of false prophecy against true prophetic word has destroyed some people's belief in the prophetic word of God. False prophets and their prophecy, instead of reducing are growing. They even challenge the true prophets openly as Hananiah did to Jeremiah. Like Jeremiah, the true prophets show a deep sense of morality towards God and his prophetic messages. They do not want the divine message contaminated with self proclaimed messages of prophets that partake in false prophecy. It should be remarked here that distinguishing the true prophet from the false is not easy. One is to be careful in patronizing them and guard against making themselves easy prey for deception. The prevalent worldview of 
our people concerning easy solution to life's problems that lead to abuse of prophetic consultation needs to be changed. The world has always been with problems and there are steps to solving them. Jeremiah is our archetypal true prophet and he truly prophesies that physically and spiritually one must go through what one is designed to unless there is repentance. This is why he is the true prophet. Hananiah remains the symbol of prophetic lie; he falsely prophesies that one's wish to escape what is meant for one in flesh and spirit without repentance is possible. This is why he is the false prophet. This tip-off should serve as lux in tenebris in differentiating between the true and the false prophets.

Ikenna L. Umeanolue

Department of Religion \& Human Relations

Nnamdi Azikiwe University

Awka, Nigeria

il.umeanolue@unizik.edu.ng

\section{References}

Carroll, R.P. (1981). From chaos to covenant: Uses of prophecy in the book of Jeremiah. London: SCM.

Dyer, C. H. and Merrill, E. H. (1999). The Old Testament Explorer. Nashville: Word.

Gallagher, P. (2014). Discerning true and false prophecy in the book of Jeremiah. Asia Journal of Theology. 28. 1. 3-15

Keil, C. F. and Delitzsch, F. (2006). Jeremiah and Lamentations. In C. F. Keil and F. Delitzsch (Eds.). Commentary on the Old Testament (vol. 8). Massachusetts: Hendrickson.

Lindblom, J. (1973). Prophecy in ancient Israel. Oxford: Basil Blackwell. 
Mandel, D. (2007). The ultimate who is who in the Bible. Alachua, Florida: Bridge-Logos.

Matthews, 1. G. (1918). How to interpret Old Testament prophecy.

The Biblical World. 52.3. 326-334. Retrieved September 28, 2013 from http://www.jstor.Org/stable/3136016.

Mowvely, H. (1979). Guide to Old Testament prophecy. London: Lutterworth.

Obielosi, D. (2012). John 11:49-52: An involuntary prophecy with part fulfillment (An exegetico-hermeneutical appraisal). Journal of Religion and Human Relations. 1. 4. 128-148.

Opeyemi, S. (2009). False prophets and pastors in Nigeria. Retrieved November 15, 2013 from http://www.google.com.ng.

Overholt, T. W. (1967). Jeremiah 27-29: The question of false prophecy. Journal of the American Academy of Religion. 35. 3. 241-249. Retrieved September 25, 2013 from http://www.jstor.org/stable/1461631.

Price, P. A. (2006). The prophet's dictionary: The ultimate guide to supernatural wisdom. New Kensington: Whitaker House.

Von Rad, G. (1968). The message of the prophets. London: SCM. Ugwueye, L. E. (2002). Prophets and prophecy in the Old Testament. Nsukka: Prize.

Ugwueye, L. E. (2004). The $10^{\text {th }}$ July Abduction Incident in Anambra state: Its Ethical implication for Democtatic Governance in Nigeria. In J.E. Madu et al (ed) in Unizik Journal of Arts and Humanities. Vol. v.(101-123)

Ugwueye, L.E. and Umeanolue, I.L. (2015). True and false prophecy in 'All Christian Practical Praying Band (ACPPB)', Ufuma, in the light of Jeremiah 27-28. 
International Journal of Religion \& Human Relations. 7. 2. 67-81.

Vine, W. E. (1996). Vine's complete expository dictionary of Old and New Testament words. Nashville: Thomas Nelson.

Vangemeren, W. A. (1990). Prophets, the freedom of God, and hermeneutics. Westminster Theological Journal. 52. 1. 7999. Retrieved September 24, 2013 from http://www.biblicalstudies.org.uk /article_god_vangemeren. html. 